(c) American Dairy Science Association, 2007.

\title{
Effects of Time at Suboptimal pH on Rumen Fermentation in a Dual-Flow Continuous Culture System
}

\author{
M. Cerrato-Sánchez, S. Calsamiglia, ${ }^{1}$ and A. Ferret \\ Grup de Recerca en Nutrició, Maneig i Benestar Animal, Departament de Ciència Animal i dels Aliments, \\ Universitat Autònoma de Barcelona 08193-Bellaterra, Spain
}

\begin{abstract}
Ruminal $\mathrm{pH}$ varies considerably during the day, achieving values below 6.0 when cows consume large amounts of concentrates. Low ruminal $\mathrm{pH}$ has negative effects on ruminal fermentation. However, previous studies have indicated that rumen bacteria may resist short periods of low ruminal $\mathrm{pH}$, and it is not clear how long this period may be before rumen microbial fermentation is negatively affected. Seven dual-flow continuous culture fermenters $(1,320 \mathrm{~mL})$ were used in 3 replicated periods with the same diet $(97 \mathrm{~g}$ of dry matter/d of a 60:40 forage-to-concentrate diet, 18.3\% crude protein, $35.9 \%$ neutral detergent fiber), temperature $\left(39^{\circ} \mathrm{C}\right)$, and solid $(5 \% / \mathrm{h})$ and liquid $(10 \% / \mathrm{h})$ dilution rates to study the effects of increasing time at suboptimal $\mathrm{pH}$ on rumen microbial fermentation and nutrient flow. Treatments were a constant $\mathrm{pH}$ of 6.4 and 6 different intervals of time during the day $(4,8,12,16,20$, $24 \mathrm{~h}$ ) at suboptimal $\mathrm{pH}$ (5.5), with the rest of the day being at $\mathrm{pH}$ 6.4. Polynomial equations were derived using the Mixed procedure of SAS, and linear, quadratic and cubic terms were left in the equation if $P<0.10$. True organic matter digestion decreased with increasing time at suboptimal $\mathrm{pH}$ and was best described by a cubic regression $\left(\right.$ TOMD $=58.5-2.15 \mathrm{x}+0.16 \mathrm{x}^{2}-$ $\left.0.0037 \mathrm{x}^{3} ; \mathrm{R}^{2}=0.74\right)$. Digestion of NDF $(\mathrm{DNDF}=55.1$ - 1.00x; $\left.R^{2}=0.75\right)$ and digestion of $\mathrm{ADF}(\mathrm{DADF}=56.2$ $-1.33 \mathrm{x} ; \mathrm{R}^{2}=0.78$ ) decreased linearly with increasing time at suboptimal $\mathrm{pH}$. Total VFA had a cubic response $\left(\mathrm{VFA}=112.7-2.09 \mathrm{x}+0.17 \mathrm{x}^{2}-0.0054 \mathrm{x}^{3} ; \mathrm{R}^{2}=0.82\right)$. The proportion of acetate decreased linearly (acetate $=$ $\left.58.7-0.61 \mathrm{x} ; \mathrm{R}^{2}=0.79\right)$. The propionate proportion increased (propionate $=17.6+2.09 \times-0.044 \mathrm{x}^{2} ; \mathrm{R}^{2}=0.85$ ) and branched-chain VFA decreased (BCVFA $=4.45-$ $\left.0.51 \mathrm{x}+0.014 \mathrm{x}^{2} ; \mathrm{R}^{2}=0.75\right)$ quadratically. The ammonia $\mathrm{N}$ concentration $\left(\mathrm{NH}_{3}-\mathrm{N}=5.85-0.13 \mathrm{x} ; \mathrm{R}^{2}=0.46\right)$ and flow $\left(\mathrm{NH}_{3}-\mathrm{N}\right.$ flow $\left.=0.18-0.0039 \mathrm{x} ; \mathrm{R}^{2}=0.43\right)$ decreased linearly as the time at suboptimal $\mathrm{pH}$ increased. Crude
\end{abstract}

Received August 9, 2006.

Accepted November 13, 2006.

${ }^{1}$ Corresponding author: Sergio.Calsamiglia@uab.es protein degradation $\left(\mathrm{CPd}=41.9-1.60 \mathrm{x}+0.060 \mathrm{x}^{2} ; \mathrm{R}^{2}=\right.$ $0.71)$, efficiency of microbial protein synthesis (EMPS = $\left.26.6-0.33 \mathrm{x}+0.021 \mathrm{x}^{2} ; \mathrm{R}^{2}=0.77\right)$, microbial $\mathrm{N}$ flow $(\mathrm{MN}$ flow $\left.=1.38-0.036 \mathrm{x}+0.0015 \mathrm{x}^{2} ; \mathrm{R}^{2}=0.77\right)$, and dietary $\mathrm{N}$ flow $\left(\mathrm{DN}\right.$ flow $\left.=1.49+0.041 \mathrm{x}-0.0015 \mathrm{x}^{2} ; \mathrm{R}^{2}=0.65\right)$ had a quadratic response. The flow of essential, nonessential, and most individual AA increased linearly with increasing time at suboptimal $\mathrm{pH}$. The effects of $\mathrm{pH}$ on rumen fermentation appear to start as soon as $\mathrm{pH}$ drops to suboptimal $\mathrm{pH}$.

Key words: acidosis, $\mathrm{pH}$, rumen fermentation

\section{INTRODUCTION}

High-producing dairy cows require high-concentrate diets to meet their productive potential. The intake of large amounts of concentrate decreases ruminal $\mathrm{pH}$, which has negative effects on rumen microbial fermentation. Low $\mathrm{pH}$ affects rumen fermentation and microbial growth (Russell and Dombrowski, 1980; Mould and Ørskov, 1983; Hoover, 1986), but most current feeding systems for dairy cattle (INRA, 1989; AFRC, 1993; NRC, 2001) do not include the effect of $\mathrm{pH}$ in their models. Others (Dijkstra et al., 1992; Pitt et al., 1996) are able to predict $\mathrm{pH}$ changes and include the effects of the decrease in ruminal $\mathrm{pH}$ on microbial fermentation, but they use a threshold average $\mathrm{pH}$ below which microbial fermentation and nutrient digestion are affected and do not consider the effects of diurnal $\mathrm{pH}$ fluctuations. For example, the Cornell Net Carbohydrate and Protein System (Pitt et al., 1996) uses an average $\mathrm{pH}$ of 6.2 as the threshold below which the growth of fiber-utilizing microbes and the rates of structural carbohydrate digestion are depressed, and it assumes that structural carbohydrates are not degraded below $\mathrm{pH}$ 5.8. The experiment reported here is part of a larger project that evaluates the effects of ruminal $\mathrm{pH}$ and its fluctuations on rumen microbial fermentation in vitro. Previous studies (Cardozo et al., 2000, 2002) have evaluated the effect of $\mathrm{pH}$ and the type diet on rumen microbial fermentation and have identified ruminal $\mathrm{pH}$ of 6.4 and 5.5 as being optimal and suboptimal, respectively. Calsamiglia et al. (2002) evaluated the effects of $\mathrm{pH}$ fluctuations and observed that constant low $\mathrm{pH}$ 
reduced $\mathrm{OM}$, fiber, and protein degradation, whereas transitory decreases of $\mathrm{pH}$ below the optimal level had either small or insignificant effects. These results agree with those of Sauvant et al. (1999) and de Veth and Kolver (2001b), who indicated that rumen bacteria might resist short periods of low ruminal $\mathrm{pH}$ without affecting overall fermentation. However, it is necessary to determine for how long the $\mathrm{pH}$ may be suboptimal before rumen microbial fermentation is negatively affected. In fact, the effects of $\mathrm{pH}$ fluctuations on microbial fermentation and nutrient flow have been identified as one of the research needs to improve the prediction of nutrient digestion in the rumen (de Veth and Kolver, 2001b; Calsamiglia et al., 2002). The objective of this study was to determine the effect of transitory reductions of $\mathrm{pH}$ to a suboptimal level (5.5) on rumen microbial fermentation and nutrient flow from a dualflow continuous culture system.

\section{MATERIALS AND METHODS}

Seven 1,320-mL dual-flow continuous culture fermenters (Hoover et al., 1976) were used in 3 replicated periods of $8 \mathrm{~d}$. Fermenters were inoculated with ruminal fluid obtained from a rumen-fistulated lactating dairy cow fed a $60 \%$ forage and $40 \%$ concentrate diet. Temperature $\left(38.5^{\circ} \mathrm{C}\right)$, and liquid $(10 \% / \mathrm{h})$ and solid $(5 \% /$ h) dilution rates were held constant and were monitored using a personal computer and LabView software (FieldPoint; National Instruments, Austin, TX). Anaerobic conditions were maintained by infusing $\mathrm{N}_{2}$ at a rate of $40 \mathrm{~mL} / \mathrm{min}$. Artificial saliva (Weller and Pilgrim, 1974) was continuously infused into flasks and contained $0.4 \mathrm{~g} / \mathrm{L}$ of urea to simulate recycled N. Treatments were a constant optimal pH (6.4), a constant suboptimal $\mathrm{pH}$ (5.5), and 5 different intervals of time $(4,8,12,16,20 \mathrm{~h})$ at a suboptimal $\mathrm{pH}(5.5)$ during each day. During the remainder of each day, $\mathrm{pH}$ was controlled at $\mathrm{pH}$ 6.4. Ruminal $\mathrm{pH}$ was controlled at either optimal $\mathrm{pH}(6.4 \pm 0.05)$ or suboptimal $\mathrm{pH}(5.5 \pm$ 0.05 ) by automatic infusion of $3 \mathrm{~N} \mathrm{HCl}$ or $5 \mathrm{~N} \mathrm{NaOH}$. Consumption of $\mathrm{NaOH}$ averaged $19.5 \mathrm{~mL} / \mathrm{d}$ and was not affected by treatment, and consumption of $\mathrm{HCl}(\mathrm{mL} /$ d) increased linearly with increasing time at suboptimal $\mathrm{pH}(\mathrm{y}=20.7+1.03 \mathrm{x})$. All fermenters were fed $97 \mathrm{~g}$ of $\mathrm{DM} / \mathrm{d}$ of a $60: 40$ forage-to-concentrate $\operatorname{diet}(18.4 \% \mathrm{CP}$, $35.0 \% \mathrm{NDF}$, and $21.0 \% \mathrm{ADF}, \mathrm{DM}$ basis) added in equal portions at 0800,1600 , and $2400 \mathrm{~h}$. The diet consisted of (DM basis) $38.0 \%$ alfalfa hay, $20.4 \%$ ground corn grain, $17.5 \%$ ground corn silage, $14.6 \%$ soybean meal, $8.8 \%$ ground barley grain, $0.22 \%$ white salt, and $0.48 \%$ of a vitamin and mineral mix, and was designed to meet or exceed current nutrient recommendations for a Holstein cow (650 kg of BW) producing $30 \mathrm{~kg}$ of milk
(NRC, 2001). The vitamin and mineral mix contained (in $1 \mathrm{~kg}$ ) $7 \mathrm{mg}$ of $\mathrm{Co}, 167 \mathrm{mg}$ of $\mathrm{Cu}, 33 \mathrm{mg}$ of I, 2,660 $\mathrm{mg}$ of $\mathrm{Mn}, 27 \mathrm{mg}$ of Se, $660 \mathrm{mg}$ of $\mathrm{Zn}, 1,000 \mathrm{kIU}$ of vitamin A, $200 \mathrm{kIU}$ of vitamin $\mathrm{D}_{3}, 1,330 \mathrm{mg}$ of vitamin $\mathrm{E}, 2.67 \mathrm{~g}$ of urea, $67 \mathrm{~g}$ of $\mathrm{NaCl}, 33 \mathrm{~g}$ of $\mathrm{S}$, and $300 \mathrm{~g}$ of $\mathrm{MgO}$.

\section{Sample Collection and Processing}

Each experimental period consisted of $5 \mathrm{~d}$ for adaptation and $3 \mathrm{~d}$ for sampling. During sampling days, collection vessels were maintained at $4^{\circ} \mathrm{C}$ to impede microbial action, solid and liquid effluents were mixed daily and homogenized for $1 \mathrm{~min}$, and a 500-mL sample was removed via aspiration. Upon completion of each period, effluents from the $3 \mathrm{~d}$ of sampling were composited and mixed within the fermenter and were homogenized for 2 min. Samples were taken for total N, ammonia N, and VFA analyses. The remainder of the sample was lyophilized. Dry samples were analyzed for DM, ash, $\mathrm{NDF}, \mathrm{ADF}$, and purine contents. Bacterial cells were isolated from fermenter flasks on the last day of each period by a combination of several procedures selected to obtain the maximum detachment without affecting microbial cell integrity (Whitehouse et al., 1994). One hundred milliliters of a $0.2 \%$ methylcellulose solution and small marbles (30 at $2 \mathrm{~mm}$ and 15 at $4 \mathrm{~mm}$ in diameter) were added to each fermenter, incubated in the same fermenter flask at $39^{\circ} \mathrm{C}$ for $1 \mathrm{~h}$ to remove attached bacteria, and refrigerated at $4^{\circ} \mathrm{C}$ for $24 \mathrm{~h}$. After refrigeration, fermenter contents were agitated for $1 \mathrm{~h}$ to dislodge loosely attached bacteria. The content was filtered through cheesecloth and washed with saline solution. Bacterial cells were isolated by differential centrifugation at $1,000 \times \mathrm{g}$ for $15 \mathrm{~min}$ to eliminate feed particles, and at $20,000 \times g$ for $20 \mathrm{~min}$ to isolate the bacterial pellet. Pellets were rinsed twice with saline solution and recentrifuged at $20,000 \times g$ for $20 \mathrm{~min}$. The last rinse was done with distilled water to prevent contamination of bacteria with ash. Bacterial cells were lyophilized and analyzed for DM, ash, nitrogen, and purine contents. Digestion of OM, NDF, ADF, and CP, and flows of total, nonammonia, microbial, and dietary $\mathrm{N}$ were calculated as described by Stern and Hoover (1990).

\section{Chemical Analyses}

Effluent DM was determined by lyophilizing $200-\mathrm{mL}$ aliquots in triplicate with subsequent drying at $103^{\circ} \mathrm{C}$ in a forced-air oven for $24 \mathrm{~h}$. The DM contents of diets and bacterial samples were determined by drying samples for $24 \mathrm{~h}$ in a $103^{\circ} \mathrm{C}$ forced-air oven according to the AOAC method (AOAC, 1990). Dry samples were 
Table 1. Effect of time (h) at suboptimal $\mathrm{pH}$ (5.5) on true $\mathrm{OM}$ and fiber digestion in continuous culture of rumen fluid

\begin{tabular}{|c|c|c|c|c|c|c|c|c|c|c|c|}
\hline \multirow[b]{2}{*}{ Digestion, \% } & \multicolumn{7}{|c|}{ Treatment $^{1}$} & \multirow[b]{2}{*}{ SEM } & \multirow[b]{2}{*}{ Regression equation $^{2}$} & \multirow[b]{2}{*}{$\mathrm{R}^{2}$} & \multirow[b]{2}{*}{$\mathrm{RMSE}^{3}$} \\
\hline & $\mathrm{H}$ & L4 & L8 & L12 & L16 & L20 & L24 & & & & \\
\hline True OM & 57.6 & 54.9 & 48.0 & 48.6 & 50.7 & 50.8 & 47.6 & 1.59 & $y=58.5-2.15 x+0.16 x^{2}-0.0037 x^{3}$ & 0.74 & 2.51 \\
\hline $\mathrm{ADF}$ & 58.2 & 54.3 & 36.8 & 39.4 & 38.4 & 30.9 & 23.7 & 5.81 & $\mathrm{y}=56.2-1.33 \mathrm{x}$ & 0.78 & 7.29 \\
\hline
\end{tabular}

${ }^{1}$ Treatments: $\mathrm{H}=$ constant $\mathrm{pH} 6.4 ; \mathrm{L} 4=\mathrm{pH}$ at 6.4 except for $4 \mathrm{~h}$ at $5.5 ; \mathrm{L} 8=\mathrm{pH}$ at 6.4 except for $8 \mathrm{~h}$ at $5.5 ; \mathrm{L} 12=\mathrm{pH}$ at 6.4 except for $12 \mathrm{~h}$ at 5.5; L16 $=\mathrm{pH}$ at 6.4 except for $16 \mathrm{~h}$ at 5.5; L20 $=\mathrm{pH}$ at 6.4 except for $20 \mathrm{~h}$ at 5.5; L24 = constant $\mathrm{pH}$ at 5.5 .

${ }^{2}$ Linear, quadratic, or cubic regression was considered valid when the term of higher order was statistically significant $(P<0.10)$.

${ }^{3} \mathrm{RMSE}=$ root mean square error.

ashed overnight at $550^{\circ} \mathrm{C}$ in a muffle furnace. Fiber components of diets and effluents were analyzed sequentially by the detergent system (Van Soest et al., 1991) using thermostable $\alpha$-amylase and sodium sulfite. Total $\mathrm{N}$ contents in feed, effluents, and bacterial samples were determined by the Kjeldahl method (AOAC, 1990). Ammonia $\mathrm{N}$ was analyzed in 4-mL subsamples of filtered fluid that were acidified with $4 \mathrm{~mL}$ of $0.2 \mathrm{~N} \mathrm{HCl}$ and frozen. Samples were centrifuged at $25,000 \times g$ for $20 \mathrm{~min}$, and the supernatant was analyzed for ammonia $\mathrm{N}$ by colorimetry (Chaney and Marbach, 1962). Samples for VFA were prepared as described by Jouany (1982) using 4-methylvaleric acid as an internal standard. The analysis was performed by GLC (model 6890; Hewlett-Packard, Palo Alto, CA) using a polyethylene glycol terephthalic acid-treated capillary column (BP21; SGE, Europe Ltd., Buckinghamshire, UK). Dry effluent and mixed bacterial cells were analyzed for purine bases content by HPLC (Beckman Instruments, Palo Alto, CA) according to the procedure of Balcells et al. (1992). Amino acids were analyzed by hydrolyzing samples $(25 \mathrm{mg}$ ) with $1,000 \mu \mathrm{L}$ of $6 \mathrm{~N} \mathrm{HCl}$ containing $0.5 \mu \mathrm{L} / \mathrm{mL}$ of mercaptoethanol at $110^{\circ} \mathrm{C}$ for $22 \mathrm{~h}, 45$ min in sealed, evacuated tubes. Derivatization was conducted using the AccQ-Tag AA analysis method (Waters Co., Milford, MA). This involved derivatizing samples with $30 \mu \mathrm{L}$ per tube of Waters AccQFluor reagent (6aminoquinolyl- $N$-hydroxysuccinimidyl carbamate) at $55^{\circ} \mathrm{C}$ for $9 \mathrm{~min}, 20 \mathrm{~s}$. Amino acid analysis was performed by reversed-phase HPLC (HP1100, AccQ-Tag AA analysis column, $3.9 \times 150 \mathrm{~mm}$ silica base bonded with $\mathrm{C}_{18}$; Agilent, Santa Clara, CA) with UV-visible detection using procedures of the Waters AA analysis method, modified to ensure separation of derivatized AA. Norleucine was used as the internal standard.

\section{Statistical Analysis}

The experiment was planned as a randomized complete block design. Results were analyzed by the Mixed procedure of SAS (v. 9.1; SAS Institute, Cary, NC). A polynomial regression model, with period as a random effect and $\mathrm{pH}$ as a fixed effect, was used to study the nature of the relationship between the explanatory variable (time at suboptimal $\mathrm{pH}$ ) and the response variable. Linear, quadratic, and cubic terms were evaluated, and the model was considered valid when the term of higher order was statistically significant. Statistical significance was declared using a significance value of 0.10 . The maximum or minimum, in quadratic equations, and the inflexion point, in cubic equations, were calculated using the first derivative.

\section{RESULTS AND DISCUSSION}

When the $\mathrm{pH}$ was reduced to 5.5 for $24 \mathrm{~h}$, digestion of OM, NDF, and ADF, the concentration of total VFA and ammonia $\mathrm{N}$, the proportion of acetate, and the acetate-to-propionate ratio decreased, and the proportion of propionate and flow of AA increased, as expected (Tables 1 to 4). These results are consistent with previous reports that evaluated the effect of low $\mathrm{pH}$ on rumen microbial fermentation, except for changes in CP degradation and dietary $\mathrm{N}$ flow, which will be discussed later (Hoover et al., 1984: Shriver et al., 1986; Calsamiglia et al., 2002). However, few studies have evaluated the effects of time at suboptimal $\mathrm{pH}$ on rumen microbial fermentation (de Veth and Kolver, 2001b; Calsamiglia et al., 2002). True OM digestion decreased with increasing time at suboptimal $\mathrm{pH}$ and was best described by a cubic regression (Table 1), decreasing almost linearly up to an inflexion point at $11 \mathrm{~h}$ and $8 \mathrm{~min}$, and remained relatively constant thereafter. This result agrees with de Veth and Kolver (2001b), who also reported a linear reduction of $\mathrm{OM}$ degradation between 0 and $12 \mathrm{~h}$ at suboptimal pH. In contrast, Calsamiglia et al. (2002) observed no differences in OM digestion between a constant high $\mathrm{pH}$ (6.4) and 8 or $12 \mathrm{~h}$ at low $\mathrm{pH}$, but the low $\mathrm{pH}$ was set at $\mathrm{pH}$ 5.7. Similarly, de Veth and Kolver (2001a) found only a small reduction in OM digestion of a high-quality pasture between $\mathrm{pH} 6.2$ and $24 \mathrm{~h}$ at 5.8 , but the reduction was larger when the $\mathrm{pH}$ was 5.4. These results suggest that the effects of $\mathrm{pH}$ on $\mathrm{OM}$ 
Table 2. Effect of time (h) at suboptimal pH (5.5) on total VFA concentration and VFA profile in continuous culture of rumen fluid

\begin{tabular}{|c|c|c|c|c|c|c|c|c|c|c|c|}
\hline \multirow[b]{2}{*}{ Item } & \multicolumn{7}{|c|}{ Treatment $^{1}$} & \multirow[b]{2}{*}{ SEM } & \multirow[b]{2}{*}{ Regression equation $^{2}$} & \multirow[b]{2}{*}{$\mathrm{R}^{2}$} & \multirow[b]{2}{*}{ RMSE } \\
\hline & $\mathrm{H}$ & L4 & L8 & L12 & L16 & L20 & L24 & & & & \\
\hline $\begin{array}{l}\text { Total VFA, } \mathrm{m} M \\
\text { VFA, mol/100 mol }\end{array}$ & 113.2 & 105.4 & 104.6 & 103.1 & 100.5 & 94.7 & 86.4 & 2.62 & $y=112.7-2.09 x+0.17 x^{2}-0.0054 x^{3}$ & 0.75 & 2.51 \\
\hline Acetate & 59.2 & 57.0 & 53.8 & 50.2 & 48.5 & 44.9 & 46.3 & 1.92 & $\mathrm{y}=58.7-0.61 \mathrm{x}$ & 0.79 & 2.89 \\
\hline Propionate & 18.5 & 24.4 & 30.1 & 36.9 & 39.4 & 43.4 & 40.9 & 2.40 & $\mathrm{y}=17.6+2.09 \times-0.044 \mathrm{x}^{2}$ & 0.85 & 4.03 \\
\hline Butyrate & 14.7 & 13.1 & 11.5 & 8.7 & 8.0 & 8.2 & 8.8 & 0.93 & $\mathrm{y}=15.2-0.71 \mathrm{x}+0.018 \mathrm{x}^{2}$ & 0.79 & 1.48 \\
\hline Isobutyrate & 0.66 & 0.59 & 0.53 & 0.30 & 0.26 & 0.15 & 0.15 & 0.09 & $\mathrm{y}=0.67-0.024 \mathrm{x}$ & 0.67 & 0.15 \\
\hline BCVFA $^{4}$ & 4.69 & 2.53 & 0.83 & 0.41 & 0.38 & 0.15 & 0.15 & 0.68 & $\mathrm{y}=4.45-0.51 \mathrm{x}+0.014 \mathrm{x}^{2}$ & 0.75 & 1.01 \\
\hline Acetate:propionate & 3.30 & 2.45 & 1.86 & 1.37 & 1.24 & 1.03 & 1.14 & 0.25 & $\mathrm{y}=3.28-0.22 \mathrm{x}+0.0053 \mathrm{x}^{2}$ & 0.82 & 0.40 \\
\hline
\end{tabular}

${ }^{1}$ Treatments: $\mathrm{H}=$ constant $\mathrm{pH} 6.4 ; \mathrm{L} 4=\mathrm{pH}$ at 6.4 except for $4 \mathrm{~h}$ at $5.5 ; \mathrm{L} 8=\mathrm{pH}$ at 6.4 except for $8 \mathrm{~h}$ at $5.5 ; \mathrm{L} 12=\mathrm{pH}$ at 6.4 except for $12 \mathrm{~h}$ at 5.5; L16 $=\mathrm{pH}$ at 6.4 except for $16 \mathrm{~h}$ at 5.5; $\mathrm{L} 20=\mathrm{pH}$ at 6.4 except for $20 \mathrm{~h}$ at 5.5; L24 = constant pH at 5.5.

${ }^{2}$ Linear, quadratic, or cubic regression was considered valid when the term of higher order was statistically significant $(P<0.10)$.

${ }^{3} \mathrm{RMSE}=$ root mean square error.

${ }^{4}$ Branched-chain VFA.

degradation started to be important only when the $\mathrm{pH}$ dropped below 5.7 .

The effects of $\mathrm{pH}$ on fiber degradation are well documented (Mould and Ørskov, 1983; Hoover, 1986), but research is limited on the effect on fiber degradation during short periods of time at suboptimal $\mathrm{pH}$. Degradation of NDF and ADF decreased linearly as the time at suboptimal $\mathrm{pH}$ increased (Table 1). de Veth and Kolver (2001b) also reported a linear reduction in NDF and $\mathrm{ADF}$ digestion when incubation was conducted at increasing periods of suboptimal $\mathrm{pH}$ (5.4). Calsamiglia et al. (2002) reported no effects after 8 or $12 \mathrm{~h}$ at suboptimal $\mathrm{pH}$ on fiber degradation, although trends suggested a linear decrease and $\mathrm{pH}$ was set at 5.7. Fibrolytic bacteria do not die at low $\mathrm{pH}$ but reduce their microbial activity, because they need to maintain their protonmotive force across the cell membrane, which increases the energy requirements for maintenance, resulting in a slower growth and eventually leading to the washout of specific microbial populations from the rumen (Strobel and Russell, 1986; Russell and Wilson, 1996). Therefore, it seems reasonable that the longer the time at suboptimal $\mathrm{pH}$, the greater the reduction in fiber digestion.

Total VFA concentration decreased as the time at suboptimal $\mathrm{pH}$ increased and was best described by a cubic regression (Table 2). The inflexion point occurred at $11 \mathrm{~h}$ and $12 \mathrm{~min}$, and was consistent with changes observed in true OM degradation. The proportion of acetate decreased linearly, and the proportion of propionate increased quadratically (Table 2) and reached the maximum at $23 \mathrm{~h}$ and $45 \mathrm{~min}$, resulting in a quadratic response in the acetate-to-propionate ratio, which reached the minimum at $22 \mathrm{~h}$ and $6 \mathrm{~min}$. The proportions of butyrate and branched-chain VFA also decreased quadratically with time at suboptimal $\mathrm{pH}$.

Table 3. Effect of time (h) at suboptimal pH (5.5) on $\mathrm{N}$ metabolism of rumen microbes in continuous culture

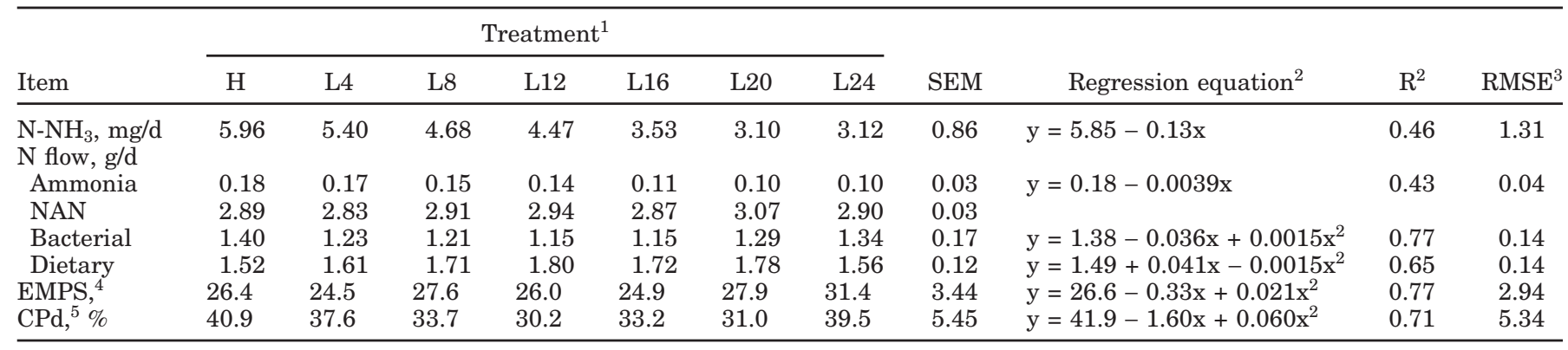

${ }^{1}$ Treatments: $\mathrm{H}=$ constant $\mathrm{pH} 6.4 ; \mathrm{L} 4=\mathrm{pH}$ at 6.4 except for $4 \mathrm{~h}$ at $5.5 ; \mathrm{L} 8=\mathrm{pH}$ at 6.4 except for $8 \mathrm{~h}$ at $5.5 ; \mathrm{L} 12=\mathrm{pH}$ at 6.4 except for $12 \mathrm{~h}$ at $5.5 ; \mathrm{L} 16=\mathrm{pH}$ at 6.4 except for $16 \mathrm{~h}$ at $5.5 ; \mathrm{L} 20=\mathrm{pH}$ at 6.4 except for $20 \mathrm{~h}$ at $5.5 ; \mathrm{L} 24=$ constant $\mathrm{pH}$ at 5.5 .

${ }^{2}$ Linear, quadratic, or cubic regression was considered valid when the term of higher order was statistically significant $(P<0.10)$.

${ }^{3} \mathrm{RMSE}=$ root mean square error.

${ }^{4}$ Efficiency of microbial protein synthesis: $\mathrm{g}$ of N/kg of OM truly digested.

${ }^{5} \mathrm{CP}$ degradation. 
Table 4. Effect of time (h) at suboptimal $\mathrm{pH}$ (5.5) on amino acid flows in continuous culture of rumen fluid

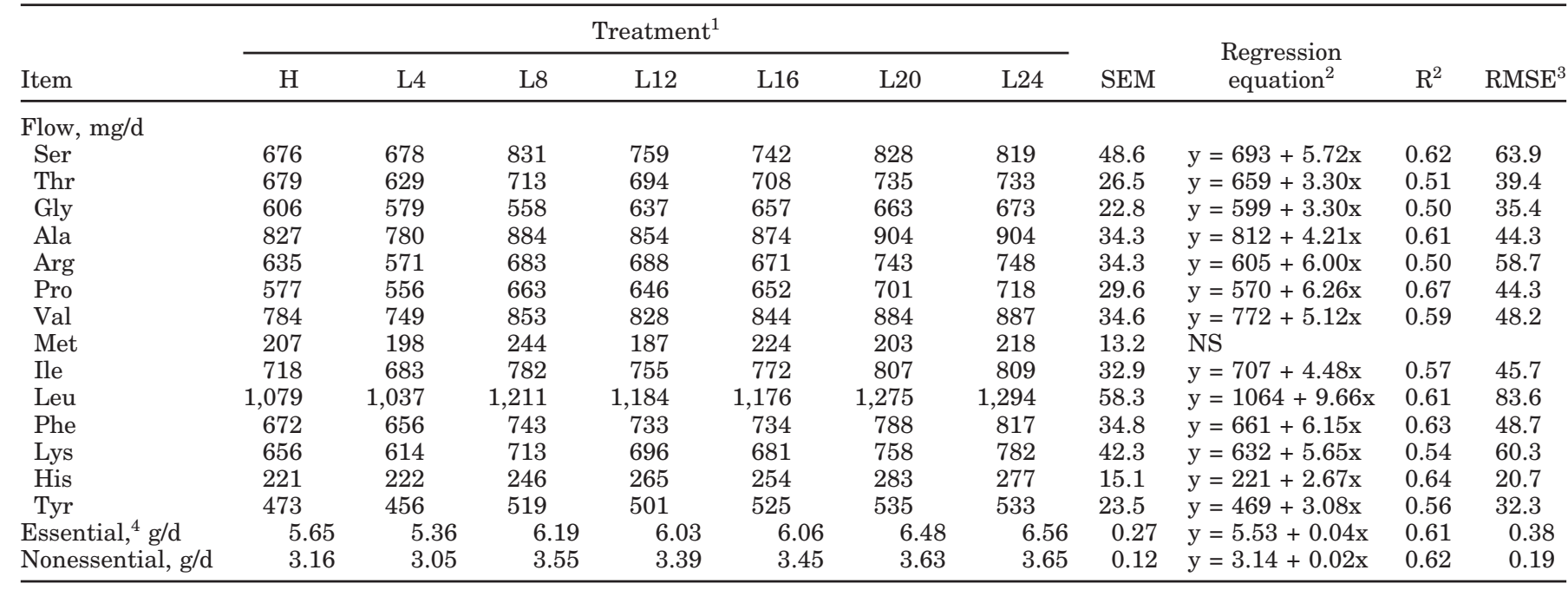

${ }^{1}$ Treatments: $\mathrm{H}=$ constant $\mathrm{pH} 6.4 ; \mathrm{L} 4=\mathrm{pH}$ at 6.4 except for $4 \mathrm{~h}$ at $5.5 ; \mathrm{L} 8=\mathrm{pH}$ at 6.4 except for $8 \mathrm{~h}$ at $5.5 ; \mathrm{L} 12=\mathrm{pH}$ at 6.4 except for $12 \mathrm{~h}$ at $5.5 ; \mathrm{L} 16=\mathrm{pH}$ at 6.4 except for $16 \mathrm{~h}$ at $5.5 ; \mathrm{L} 20=\mathrm{pH}$ at 6.4 except for $20 \mathrm{~h}$ at 5.5; L24 = constant $\mathrm{pH}$ at 5.5 .

${ }^{2}$ Linear, quadratic, or cubic regression was considered valid when the term of higher order was statistically significant $(P<0.10)$.

${ }^{3} \mathrm{RMSE}=$ root mean square error.

${ }^{4}$ Essential AA: Thr, Arg, Val, Met, Ile, Leu, Phe, Lys, His; nonessential AA: Ser, Gly, Ala, Pro, Tyr.

de Veth and Kolver (2001b) observed that increasing the time at suboptimal $\mathrm{pH}$ (up to $12 \mathrm{~h}$ ) resulted in a decrease in total VFA and acetate concentrations and an increase in the propionate concentration in response to increasing time at suboptimal $\mathrm{pH}$, although time at suboptimal $\mathrm{pH}$ had no effect on the butyrate concentration. Calsamiglia et al. (2002) reported similar trends when incubations were conducted at suboptimal $\mathrm{pH}$ for 8 or $12 \mathrm{~h}$, although differences were not always significant. Changes in the proportions of VFA are likely related to the reduction in fiber digestion. The reduction in branched-chain VFA with increasing time at suboptimal $\mathrm{pH}$ is likely due to a reduced deamination of $\mathrm{AA}$ at low $\mathrm{pH}$, and agrees with the lower ammonia $\mathrm{N}$ concentration reported. Because branched-chain VFA are essential growth factors for fibrolytic bacteria (Slyter and Weaver, 1971), the negative effect of low $\mathrm{pH}$ on fibrolytic bacteria may have been aggravated by the limited availability of branched-chain VFA, which was less than $1 \mathrm{~m} M$ when $\mathrm{pH}$ was 5.5 for $8 \mathrm{~h}$ or more.

The ammonia $\mathrm{N}$ concentration and flow decreased linearly as the time at suboptimal $\mathrm{pH}$ increased (Table 3 ). These results agree with those of Calsamiglia et al. (2002), who reported a lower ammonia N concentration when incubations were conducted at suboptimal $\mathrm{pH}$ for $12 \mathrm{~h}$, compared with constant $\mathrm{pH}$ at 6.4. The reduction in ammonia $\mathrm{N}$ concentration at low $\mathrm{pH}$ may be the result of a reduction in dietary protein degradation. However, CP degradation was best described by a quadratic regression, reaching the minimum of $31.2 \%$ at
$13 \mathrm{~h}$ and $18 \mathrm{~min}$, and slowly recovering up to $39.8 \%$ at $24 \mathrm{~h}$. The flow of dietary $\mathrm{N}$ was best described by a quadratic regression, reaching the maximum at $13 \mathrm{~h}$ and $21 \mathrm{~min}$. The initial decrease in CP degradation and increase in dietary $\mathrm{N}$ flow agrees with the observations of de Veth and Kolver (2001b), who also observed a reduction in CP degradation and an increase in dietary $\mathrm{N}$ flow when incubations were conducted at suboptimal $\mathrm{pH}$ for increasing periods up to $12 \mathrm{~h}$, although their response was linear. However, Calsamiglia et al. (2002) observed that protein degradation was further decreased as the time at suboptimal $\mathrm{pH}$ increased from 12 to $24 \mathrm{~h}$, and other reports have also indicated lower protein degradation after incubations were conducted at a constant suboptimal $\mathrm{pH}$ (Hoover et al., 1984; Shriver et al., 1986). The increase in protein degradation between 12 and $24 \mathrm{~h}$ in the present trial was not expected. Although one could speculate that the increase in protein degradation may reflect a shift toward amylolytic bacteria, which tend to be more proteolytic than cellulolytic bacteria (Wallace and Cotta, 1989), this was unlikely if we consider that most research has reported a reduction in $\mathrm{CP}$ degradation at low $\mathrm{pH}$ (Hoover et al., 1984; Cardozo et al., 2000; Calsamiglia et al., 2002), and it is inconsistent with the observed reduction in ammonia $\mathrm{N}$ and branched-chain VFA concentrations. Therefore, we have no clear explanation for the increase in CP degradation as time at suboptimal $\mathrm{pH}$ increased from 12 to $24 \mathrm{~h}$. Microbial nitrogen flow was best described by a quadratic equation (Table 
3), reaching the minimum at $12 \mathrm{~h}$ at suboptimal $\mathrm{pH}$. de Veth and Kolver (2001b) also observed a decrease in bacterial $\mathrm{N}$ flow (g/d) when incubations were conducted at increasing periods of suboptimal $\mathrm{pH}$ (5.4), up to $12 \mathrm{~h}$. However, they observed a linear relationship, which could have occurred because they maintained fermenters at suboptimal $\mathrm{pH}$ from 0 to $12 \mathrm{~h}$ and did not evaluate longer periods. We hypothesize that the recovery in bacterial $\mathrm{N}$ flow in the present trial could be due to a shift toward strains of bacteria that grow more efficiently at low $\mathrm{pH}$. Other authors did not observe differences in bacterial $\mathrm{N}$ flow between a constant high pH and a low pH (Calsamiglia et al., 2002; Wales et al., 2004). The efficiency of microbial protein synthesis was best described by a quadratic equation, with the lowest point occurring at $7 \mathrm{~h}$ and $53 \mathrm{~min}$. de Veth and Kolver (2001b) also observed a reduction in efficiency of microbial protein synthesis (EMPS) as incubations were conducted at increasing periods of suboptimal $\mathrm{pH}$ (5.4), but they reported a linear reduction up to $12 \mathrm{~h}$ and did not report effects of longer periods. The recovery in EMPS in the constant suboptimal $\mathrm{pH}$ (5.5) treatment to similar levels compared with the constant optimal $\mathrm{pH}$ (6.4) treatment is in agreement with the results of Calsamiglia et al. (2002) and Cardozo et al. (2000), who did not find significant differences in EMPS between a constant $\mathrm{pH}$ of 6.5 and a constant suboptimal $\mathrm{pH}$. However, others have reported that when incubations are conducted at a constant suboptimal $\mathrm{pH}$, the EMPS increases compared with $\mathrm{pH}$ above 6.0 (Shriver et al., 1986; de Veth and Kolver, 2001a; Wales et al., 2004).

Increasing the time at suboptimal $\mathrm{pH}$ resulted in a linear increase in the flow $(\mathrm{mg} / \mathrm{d})$ of individual (except Met), essential, and nonessential AA (Table 4). This is in agreement with Calsamiglia et al. (2002), who reported a higher flow of total and essential AA, Gly, Lys, Leu, His, and Arg when incubations were conducted at a constant $\mathrm{pH}$ of 5.7 compared with a constant $\mathrm{pH}$ of 6.4. It is likely that a marginal acidosis may be beneficial for dairy cattle from the standpoint of protein nutrition.

\section{CONCLUSIONS}

Low $\mathrm{pH}$ affected rumen microbial fermentation and nutrient flow in continuous culture fermenters. The effects of time at suboptimal $\mathrm{pH}$ were different depending on the factor measured. Overall, the effects of $\mathrm{pH}$ on rumen fermentation appeared to take place as soon as the $\mathrm{pH}$ started to become suboptimal. The largest effects occurred within the first $12 \mathrm{~h}$ of suboptimal $\mathrm{pH}$ and, in most cases, longer periods had only small additional effects. From the standpoint of protein nutrition, low $\mathrm{pH}$ resulted in an improved flow of total and essential AA.

\section{ACKNOWLEDGMENT}

Financial support was provided by the Spanish Ministry of Education, Culture and Sport (Project AGL 2002-01642).

\section{REFERENCES}

AFRC (Agricultural and Food Research Council). 1993. Energy and Protein Requirements of Ruminants. Advisory manual prepared by the Agric. Food Res. Counc. Technical Committee on Responses to Nutrients. CAB International, Wallingford, UK.

AOAC. 1990. Official Methods of Analysis. 15th ed. AOAC International, Arlington, VA.

Balcells, J., J. A. Guada, J. M. Peiró, and D. S. Parker. 1992. Simultaneous determination of allantoin and oxypurines in biological fluids by high performance liquid chromatography. J. Chromatogr. 575:153-157.

Calsamiglia, S., A. Ferret, and M. Devant. 2002. Effects of $\mathrm{pH}$ and $\mathrm{pH}$ fluctuations on microbial fermentation and nutrient flow from a dual-flow continuous culture system. J. Dairy Sci. 85:574-579.

Cardozo, P. W., S. Calsamiglia, and A. Ferret. 2002. Effects of pH on microbial fermentation in high concentrate diets in a dual flow continuous culture system. J. Dairy Sci. 85(Suppl. 1):182. (Abstr.)

Cardozo, P. W., S. Calsamiglia, and A. Ferret. 2000. Effects of pH on microbial fermentation and nutrient flow in a dual flow continuous culture system. J. Dairy Sci. 83(Suppl. 1):265. (Abstr.)

Chaney, A. L., and E. P. Marbach. 1962. Modified reagents for determination of urea and ammonia. Clin. Chem. 8:130-132.

de Veth, M. J., and E. S. Kolver. 2001a. Digestion of ryegrass pasture in response to change in $\mathrm{pH}$ in continuous culture. J. Dairy Sci. 84:1449-1457.

de Veth, M. J., and E. S. Kolver. 2001b. Diurnal variation in $\mathrm{pH}$ reduces digestion and synthesis of microbial protein when pasture is fermented in continuous culture. J. Dairy Sci. 84:2066-2072.

Dijkstra, J., H. D. St, C. Neal, D. E. Beever, and J. France. 1992. Simulation of nutrient digestion, absorption and outflow in the rumen: Model description. J. Nutr. 122:2239-2256.

Hoover, W. H. 1986. Chemical factors involved in ruminal fiber digestion. J. Dairy Sci. 69:2755-2766.

Hoover, W. H., B. A. Crooker, and C. J. Sniffen. 1976. Effects of differential solid-liquid removal rates on protozoa numbers in continuous cultures of rumen contents. J. Anim. Sci. 43:528-534.

Hoover, W. H., C. R. Kincaid, G. A. Varga, W. V. Thayne, and L. L. Junkins. 1984. Effects of solids and liquid flows on fermentation in continuous cultures. IV. $\mathrm{pH}$ and dilution rate. J. Anim. Sci. 58:692-699.

INRA (l'Institut National de la Recherche Agronomique). 1989. Ruminant Nutrition: Recommended Allowances and Feed Tables. R. Jarrige, ed. Libbey Eurotext, Paris.

Jouany, J. P. 1982. Volatile fatty acids and alcohol determination in digestive contents, silage juice, bacterial cultures and anaerobic fermenter contents. Sci. Aliments 2:131-144.

Mould, F. L., and R. E. Ørskov. 1983. Manipulation of rumen fluid $\mathrm{pH}$ and its influence on cellulolysis in sacco, dry matter degradation and the ruminal microflora of sheep offered either hay or concentrate. Anim. Feed Sci. Technol. 10:1-14.

NRC. 2001. Requirements of Dairy Cattle. 7th rev. ed. National Academy Press, Washington, DC.

Pitt, R. E., J. S. Van Kessel, D. G. Fox, A. N. Pell, M. C. Barry, and P. J. Van Soest. 1996. Prediction of ruminal volatile fatty acids and $\mathrm{pH}$ within the net carbohydrate and protein system. J. Anim. Sci. 74:226-244.

Russell, J. B., and D. B. Dombrowski. 1980. Effect of $\mathrm{pH}$ on the efficiency of growth by pure cultures of rumen bacteria in continuous culture. Appl. Environ. Microbiol. 39:604-610. 
Russell, J. B., and D. B. Wilson. 1996. Why are ruminal cellulolytic bacteria unable to digest cellulose at low pH? J. Dairy Sci. 79:1503-1509.

Sauvant, D., F. Meschy, and D. R. Mertens. 1999. Les composantes de l'acidose ruminale et les effets acidogenes des rations. INRA Prod. Anim. 12:49-60.

Shriver, B. J., W. H. Hoover, J. P. Sargent, R. J. Crawford Jr., and W. V. Thayne. 1986. Fermentation of a high concentrate diet as affected by ruminal $\mathrm{pH}$ and digesta flow. J. Dairy Sci. 69:413-419.

Slyter, L. L., and J. M. Weaver. 1971. Growth factor requirements of ruminal cellulolytic bacteria isolated from microbial populations supplied diets with or without rapidly fermentable carbohydrate. Appl. Microbiol. 22:930-932.

Stern, M. D., and W. H. Hoover. 1990. The dual flow continuous culture system. Pages 17-32 in Proc. Continuous Culture Fermenters: Frustration or Fermentation. Northwest ADSA-ASAS Regional Meeting, Chazy, NY.

Strobel, H. J., and J. B. Russell. 1986. Effect of $\mathrm{pH}$ and energy spilling on bacterial protein synthesis by carbohydrate-limited cultures of mixed rumen bacteria. J. Dairy Sci. 69:2941-2947.
Van Soest, P. J., J. B. Robertson, and B. A. Lewis. 1991. Methods for dietary fiber, neutral detergent fiber and nonstarch polysaccharides in relation to animal nutrition. J. Dairy Sci. 74:35833597.

Wales, W. J., E. S. Kolver, P. L. Thorne, and A. R. Egan. 2004. Diurnal variation in ruminal $\mathrm{pH}$ on the digestibility of highly digestible perennial ryegrass during continuous culture fermentation. J. Dairy Sci. 87:1864-1871.

Wallace, R. J., and M. A. Cotta. 1989. Metabolism of nitrogen-containing compounds. Pages 217-250 in The Rumen Microbial Ecosystem. P. N. Hobson, ed. Elsevier Applied Science, New York, NY.

Weller, R. A., and A. F. Pilgrim. 1974. Passage of protozoa and volatile fatty acids from the rumen of a sheep and from a continuous in vitro fermentation system. Br. J. Nutr. 32:341-351.

Whitehouse, N. L., V. M. Olson, C. G. Schwab, W. R. Chesbro, K. D. Cunninghan, and K. D. Lycos. 1994. Improved techniques for dissociating particle-associated mixed ruminal microorganisms from ruminal digesta solids. J. Anim. Sci. 72:1335-1343. 